\title{
Teksty nadesłane
}

DOI: $10.14746 /$ por.2018.2.19

\section{SYNOWIE STASIA. FORMY MĘSKOŚCI KOLONIALNEJ W POWIEŚCIACH MŁODZIEŻOWYCH FERDYNANDA ANTONIEGO OSSENDOWSKIEGO}

\author{
WaCŁaW Forajter ${ }^{1}$ \\ (Uniwersytet Śląski w Katowicach)
}

\begin{abstract}
Słowa kluczowe: polska literatura młodzieżowa, kolonializm, dwudziestolecie międzywojenne, męska inicjacja
\end{abstract}

Keywords: Polish youth literature, colonialism, interwar period, male initiation

\begin{abstract}
Abstrakt: Wacław Forajter, SYNOWIE STASIA. FORMY MĘSKOŚCI KOLONIALNEJ W POWIEŚCIACH MŁODZIEŻOWYCH FERDYNANDA ANTONIEGO OSSENDOWSKIEGO. „PORÓWNANIA" 2 (23), 2018. T. XXIII, S. 279-295. ISSN 1733-165X. Tekst Synowie Stasia. Męskości kolonialne w powieściach młodzieżowych Ferdynanda Antoniego Ossendowskiego stanowi analizę wątków inicjacyjnych w trzech tekstach narracyjnych popularnego prozaika z czasów dwudziestolecia międzywojennego: powieści W poleskiej dżungli, Mali zwycięzcy i Skarb Wysp Andamańskich. Odwołując się do teorii postkolonialnej oraz analizy dyskursów ideologicznych Drugiej Rzeczpospolitej, autor bada powieściowe reprezentacje odmiennych kultur oraz obowiązujące wówczas w Polsce i za granicą wzorce męskości oraz sposoby ich adaptacji na potrzeby literatury dla dzieci i młodzieży.
\end{abstract}

\begin{abstract}
Wacław Forajter, THE SONS OF STAŚ. COLONIAL MASCULINITIES IN FERDYNAND ANTONI OSSENDOWSKI'S YOUTH NOVELS. "PORÓWNANIA" 2 (23), 2018. Vol. XXIII, P. 279-295. ISSN 1733-165X. The article The Sons of Staś. Colonial Masculinities in Ferdynand Antoni Ossendowski's Youth Novels analyses the motif of male initiation in three narrative texts of the Polish popular writer from the interwar period: W poleskiej dzungli [In the Polesian Jungle], Mali zwycięzcy [Little Winners] and Skarb Wysp Andamańskich [The Treasure of the Andaman Islands]. Referring to postcolonial theory and the analysis of ideological discourses of the Second Polish Republic, the author examines novels with the aim to show representations of different cultures, masculinity models that existed in Poland and abroad in that period, and methods of their adaptation for the needs of children's and youth literature.
\end{abstract}

1 E-mail: wforajter@o2.pl 
[...] lichy człowiek dobrym Polakiem być nie może.

(Pigoń 183)

\section{1. "Czarne kariatydy": formy męskości kolonialnej}

Czternastego lipca 1939 roku ulicami Paryża przeszła imponująca defilada, w czasie której wyjątkowa, pierwszoplanowa rola przypadła wojskom kolonialnym, szczególnie zaś oddziałom strzelców senegalskich. Kilka dni później dziennikarze, relacjonujący stołeczne obchody święta narodowego, porównywali ciemnoskórych wojskowych do „majestatycznych posągów z brązu” czy „czarnych kariatyd francuskich sił zbrojnych" (Joly 141). Kilka tygodni wcześniej, pod koniec czerwca, w Gdyni odbyły się kolejne, siódme Dni Morza - masowe święto o kluczowym znaczeniu dla propagandy Drugiej Rzeczpospolitej. Tamtego upalnego lata miały one szczególną wartość, stały się bowiem, jak donosiła prasa, „wielką mobilizacją powszechną całego Narodu w potężnym zrywie patriotycznej gotowości obrony tego, co dla każdego Polaka jest najdroższe - Wolności" (Lewandowski 4). W ich ramach miały miejsce między innymi defilady polskich oddziałów kolonialnych w białych mundurach i hełmach korkowych, naśladujących stroje sił militarnych światowych imperiów. Celebracja uroczystości, połączonej ze świętowaniem Dni Kolonialnych, objęła nie tylko wybrzeże, ale cały kraj: ulicami polskich miast jeździły odpowiednio udekorowane tramwaje, odbywały się uroczyste nabożeństwa i pochody.

Spośród bogatej ikonografii tych wydarzeń jednym z najbardziej skłaniających do refleksji dokumentów jest fotografia przedstawiająca dziarskiego, ciemnoskórego żołnierza w trakcie parady Polskiej Ligi Morskiej i Kolonialnej w Toruniu („Czarnoskóry żołnierz w pochodzie...", źródło elektroniczne). Bohater zdjęcia w tropikalnej mycce $z$ gigantycznym blaszanym orłem i karabinem na ramieniu wygląda co najmniej ekscentrycznie. Czyżby stanowił on żywy dowód na ziszczenie się marzeń Stasia Tarkowskiego o „murzyńskiej armii” zrealizowanych, mimo wszystko, w skrajnie trudnych warunkach geopolitycznych lat trzydziestych ${ }^{2}$ ? Nie dajmy się jednak zwieść pozorom: żołnierz ma wąskie usta i nos oraz regularne rysy twarzy, na podstawie których "specjaliści” od popularnej wówczas antropologii fizycznej niewątpliwie uznaliby go za Europejczyka. Gdy przyjrzymy mu się jeszcze bliżej, z całą oczywistością na jaw wyjdzie zainscenizowana maskarada, swoiste odwrócenie kolonialnej mimikry opisanej przez Homiego Bhabhę: to po prostu pomalowany

2 Co ciekawe, Janusz Makarczyk, pisząc po wojnie o próbie zawarcia umowy pomiędzy Ligą a rządem Liberii, wspominał między innymi o tajnej klauzuli, zgodnie z którą Polacy zmodernizują obronę graniczną afrykańskiego państwa i, w razie "konfliktu lub obawy konfliktu w Europie", będą mieli prawo przeprowadzić rekrutację do "Armii Pomocniczej”: „Wolno nam było rekrutować do stu tysięcy ludzi i przewieźć ich do Polski" (Makarczyk 73-74). Projekt, zakładany w klauzuli, oczywiście nie doszedł do skutku, a książka dyplomaty jest jej jedynym zapisanym świadectwem. 
czarną farbą Polak, imitacja Afrykanina w imitacji imperialnego munduru. Kultura dwudziestolecia chętnie reprodukowała, by sparafrazować tytuł słynnej rozprawy Frantza Farona, „,białe twarze w czarnej masce”, ale większość z nich, jak udowodniła Dorota Wojda, zdradzała europocentryczne poczucie cywilizacyjnej wyższości i wiązała się z przemocą symboliczną. Jak bowiem zauważyła badaczka,

Polacy, przez długi czas poddani obcej władzy, po uzyskaniu niepodległości skłonni byli przejmować od innych wzorce dominacji, do czego potrzebowali nie tylko umocnienia własnej tożsamości, ale też swojego Murzyna, przynajmniej w wyobraźni (Wojda 174).

Aktor-amator $\mathrm{w}$ kostiumie afrykańskiego strzelca mimowolnym uśmiechem ujawnia jednak groteskowość własnej sytuacji, a pośrednio również tragikomiczność rodzimego projektu kolonialnego w obliczu konfliktu z militarną potęgą Niemiec. W istocie bowiem te specyficzne "sny o potędze” próbowały kamuflować zapóźnienie cywilizacyjne, rosnące napięcia społeczne i etniczne (przypomnijmy hasło „Żydzi na Madagaskar”) czy anachroniczność polskich sił zbrojnych.

Ten przydługi wstęp jest uzasadniony przede wszystkim kluczową rolą różnych form męskości zachodnich w historii kolonializmu ze szczególnym wskazaniem na wzorzec militarny, który był istotny zwłaszcza we wczesnej fazie podboju, kiedy najważniejszą rolę odgrywały wybitnie męskie wspólnoty żeglarzy i żołnierzy. Później, co prawda, został on zastąpiony innymi, zmiennymi w czasie modelami męskości, jak chociażby ideałem osadnika z interioru czy przedsiębiorcy lub wykwalifikowanego pracownika fabrycznego w kolonialnych organizmach miejskich, nigdy jednak ostatecznie nie stracił na znaczeniu, ponieważ przez ponad pięćset lat ekspansja świata Zachodu nieodmiennie opierała się na argumencie siły.

Strzelec senegalski i jego fikcyjny pomorski odpowiednik mieli gwarantować bezpieczeństwo (Joly 141), ale także wzmagać ducha bojowego, potęgować poczucie męskiej sprawczości w obserwujących ich Europejczykach. Omówiony przypadek jest o tyle wyjątkowy, o ile afrykański lub azjatycki tubylec pozornie w dwojakim sensie znajdował się w sytuacji podrzędnej wobec mężczyzny Zachodu. Po pierwsze, został podbity, a zatem udowodnił własną „niemęskość”. W odniesieniu do mieszkańców Bengalu takie stanowisko reprezentował Thomas Babington Macaulay, który stwierdził:

Bengalczyk jest słabej budowy ciała, wręcz niewieściej. Nieustanne przebywa w łaźni parowej. Celem jego jest osiadły tryb życia, cechuje go cherlawość, kończyny ma delikatne, porusza się anemicznie. Przez wiele stuleci tratowały po nim tabuny mężczyzn śmielszych i w czynach bardziej zdecydowanych (cyt. za: Gandhi 93).

Po drugie, władza określania genderu, bazująca na dyskursie wynalezionym w metropoliach, należała do białych mężczyzn. Historia XIX- i XX-wiecznego kolo- 
nializmu, zwłaszcza zaś zróżnicowane formy oporu lokalnych społeczności wobec europejskiej władzy ujawniają jednak nieprawdziwość tego statycznego obrazu. Przede wszystkim, co sygnalizował Vincent Joly za Minhali Sinhą, „męskości europejskie i tubylcze” tworzyły się „w ustawicznym ruchu i powinny być analizowane w perspektywie relacji władzy”. Ewoluowały także „w miarę upływu czasu wraz ze zmianami, oddziałującymi na stosunki między kolonizatorami i skolonizowanymi" (Joly 139; Sinha). Poza tym w koloniach sensu stricto biali zetknęli się z „rasami wojowniczymi": Sikhami i Gurkhami (Indie Brytyjskie) czy ludem Bambara (francuska Afryka Zachodnia). Sikhizm od początku XVIII wieku miał formę militarną, w Indiach istniały kasty same określające się jako wojownicze (np. kszatrija, radżputowie), a państwem Bambara na terenie dzisiejszego Mali rządzili wojownicy, którzy z łupiestwa uczynili podstawowe źródło dochodu. Związany z nimi dyskurs w dużej mierze stanowił jednak bardziej wytwór inwencji Europejczyków niż odzwierciedlenie faktycznego stanu rzeczy, zresztą pierwszym wzorcem „rasy wojowniczej" stali się w XVIII wieku szkoccy górale - mieszkańcy europejskiej Północy. Idealny żołnierz tubylczy z Indii miał ucieleśniać cechy pożądane przez kolonizatora, który projektował je na wszystkich mężczyzn z danej grupy etnicznej: umiejętność panowania nad seksualnością i koncentrowania energii na wojnie oraz pracy, honor, posłuszeństwo czy lojalność, którą rozumiano jako zaletę wybitnie męską, pozwalającą więc uznać za zniewieściałych wszystkich tych, którzy nie podporządkowywali się władzy imperialnej (Joly 143-144). Co ciekawe, w wielu przypadkach samo przeniesienie form męskości metropolitarnej, podobnie zresztą jak okcydentalnych wzorców kobiecości, w nowy kontekst kulturowy sprawiało, że ulegały one daleko posuniętej erozji i trzeba je było rekonstruować w oparciu o specyfikę nowych społeczeństw. Problem ten przedstawia Raewyn Connell:

Wczesna historia kolonii osadniczych, jak np. brytyjska kolonizacja Australii wypełniona jest debatami o seksualnej anarchii i rozregulowaniu ról płciowych [...]. W historii kolonii jako efektu podboju, jak holenderskie Indie Wschodnie (dzisiejsza Indonezja) wiek dziewiętnasty był świadkiem postępującej regulacji seksualności oraz kreowania ograniczeń małżeńskich w oparciu o kryteria rasowe (Connell, źródło elektroniczne).

Jak dalej przekonuje australijska badaczka, wszystkie występujące wówczas próby normatywizowania obowiązujących $\mathrm{w}$ koloniach wzorów genderowych zmierzały do wprowadzenia zachodnich odmian męskości hegemonicznej, co jednak rzadko stawało się „faktem dokonanym”. Hierarchie, które usankcjonował kolonializm XIX i pierwszej połowy XX wieku, podobnie jak późniejsze systemy zależności, nadal jednak mają decydujący wpływ na kanony męskości obecne w krajach półperyferyjnych i peryferyjnych. 


\section{2. "Duzi" wodzowie: formy inicjacji w powieściach Ossendowskiego}

Analiza kategorii płciowych w literaturze polskiej eksplorującej tematy kolonialne $z$ kilku powodów jest zadaniem trudnym. Problematyczność zagadnienia nie wynika jedynie z faktu, iż mamy do czynienia ze zjawiskiem czysto retorycznym, niemającym rzeczywistego zakorzenienia w praktykach politycznych i społecznych, które składały się na style funkcjonowania odmiennych populacji w posiadłościach zamorskich zachodnich mocarstw. Wiąże się również z pytaniem, w jaki sposób i na ile typowo polskie wzorce męskości przenikały się z tymi, które były praktykowane przez mieszkańców Starego Świata poza Europą. By to ustalić, należy poddać analizie zależności pomiędzy residuami etosu rycerskiego, nowoczesną męskością militarną i „człowiekiem ekonomicznym”. Kolejne utrudnienie wprowadza specyfika literatury dziecięcej okresu dwudziestolecia międzywojennego z jej tematami tabu, uproszczonym obrazem społeczeństwa czy - nieraz nachalnym - przesłaniem dydaktycznym. Trzeba więc prześledzić właściwe jej chwyty retoryczne i schematy fabularne oraz uchwycić ich relacje wobec ideologii kolonialnej w wersji "dla dorosłych".

W planie symbolicznym ukazane wcześniej figury tubylczych żołnierzy stanowiły odpowiedź na kryzys europejskiej męskości mieszczańskiej, obserwowany od drugiej połowy XIX wieku, kiedy dostrzeżono, że

gwałtowna i obejmująca wszystkie sfery życia modernizacja ma negatywny wpływ na tę hegemoniczną męskość: obniża sprawność fizyczną, mężczyźni tyją, rozleniwiają się, feminizują, stają się nadmiernie wyrafinowani, zapadają na nerwach, tracą kontrolę nad swoją popędowością. Sytuacja ta ma wpływ na życie społeczne i bezpośrednio dotyka tak ważnej kategorii jak naród. W całej Europie mnożą się ruchy mające na celu konsolidację tożsamości narodowych wokół idei „wzmocnienia męskości” za pomocą rygorystycznych ćwiczeń fizycznych, sportu, polowań, wędrówek górskich etc. (Śmieja 2016: 101) $)^{3}$.

Na ziemiach polskich pod zaborami postulat „wzmocnienia” męskości, stanowiący próbę zaradzenia postępującej „degeneracji” społeczeństwa, podjęli między innymi rzecznicy skautingu, wśród których istotną rolę odgrywali działacze towarzystw gimnastycznych, zatroskani w tym samym stopniu o tężyznę fizyczną młodych mężczyzn, co o ich edukację patriotyczną. Antoni Małkowski, jeden z prekursorów harcerstwa i członek "Zarzewia” wskazywał na związki Baden-Powellowskiej „szkoły charakterów” (Małkowski 3) z ideą służby ojczyźnie, co oczywiście miało inne implikacje na obszarze Imperium Brytyjskiego, odmienne

3 Kryzys ten pogłębił się po Wielkiej Wojnie (Joly 140-141). 
zaś na terenie Kongresówki i Galicji. Stąd pierwsze numery „Skauta”, wydawanego od 1911 roku we Lwowie, oprócz informacji na temat rozwoju ruchu na Zachodzie i porad praktycznych zawierały również pieśni patriotyczne, wskazówki moralne oraz artykuły poświęcone „organizacji pracy narodowej” (A.M. 4), a samo pojęcie "harcerza” wywodzono od rycerza-,,harcownika”, uznając członków organizacji za spadkobierców Zawiszy Czarnego, Michała Wołodyjowskiego i Mohorta. Nic więc dziwnego, że wielu polskich skautów kilka lat później zamieniło kapelusze na szare maciejówki, przystępując do Legionów. Po uzyskaniu niepodległości polska męskość częściowo pozbyła się „płaszcza Konrada”, ale już

w 1932 roku działa 5259 stowarzyszeń sportowych zrzeszających 289,5 tysiąca ćwiczących, a w 1938 roku stowarzyszeń jest już 8188 z 469,5 tysięcy ćwiczących. Wychowanie fizyczne łączy się ściśle z przysposobieniem wojskowym, Towarzystwo Sportowe "Sokół” czy Związek Strzelecki „Strzelec" dążą do stworzenia wzorcowego „obywatela-żołnierza". W statucie drugiej z tych organizacji (o jej potędze świadczy 0,5 miliona członków w 1938 roku) przeczytamy, że nadrzędnym celem jest „rozbudzanie i hartowanie wśród członków ducha narodowego, karności, dzielności moralnej, sprawności fizycznej oraz szerzenie wiedzy wojskowej”. Wychowanie "strzeleckie" cechowało: kult wodza ([Józefa] Piłsudskiego, potem Edwarda Rydza-Śmigłego), militaryzm i antykomunizm (Śmieja 2011: 30).

Do listy organizacji zrzeszających młodych, umundurowanych mężczyzn dodajmy jeszcze oddziały kolonialne zorganizowane przez Ligę Morską i Kolonialną podlegającą wojsku, a uzyskamy pełny obraz zjawiska w latach trzydziestych. Nieco młodszym Polakom pozostawało harcerstwo, pełniące również ważną funkcję, miało bowiem przyczynić się do „wytworzenia nowego, lepszego typu człowieka, urobienia całokształtu człowieka i Polaka" (Muszalski 3), dla którego miłość do przyrody i historii kraju miała wiązać się z afirmacją państwa o „określonym porządku prawno-politycznym" (Budrewicz 31).

Literatura młodzieżowa z lat 1918-1939 promowała określone modele męskości, wpisując je często w fabuły inicjacyjne. Niewątpliwie jednym z najbardziej popularnych był lotnik, celebryta epoki, łączący męskość militarną z nowym wzorcem sportowca, znany w wersji dla dorosłych z powieści Janusza Meissnera:

Urzeczenie widokiem aeroplanu w powietrzu było wspólnym doświadczeniem pokolenia dorastającego w okresie Drugiej Rzeczypospolitej. Sztandary z hasłami „Lotnictwo naszym sportem narodowym”, „Polska krajem lotnictwa” dumnie powiewały nad głowami tłumów oglądających w Warszawie zawody samolotów turystycznych Challenge w 1934 roku. Długodystansowe loty, popisy akrobacji lotniczych lub szybowcowych na lotniskach aeroklubów stolicy, Krakowa, Lwowa, Poznania, rekordy uzyskiwane na maszynach rodzimej konstrukcji w wykonaniu asów lotnictwa sportowego i wojskowego 
tej klasy co Franciszek Żwirko i Bolesław Orliński - tego rodzaju wydarzenia przykuwały uwagę całego społeczeństwa. Na pierwszych stronach gazet dziennikarze entuzjastycznie komentowali wyczyny Bajana, Skarżyńskiego, Płonczyńskiego. Uwielbienie dla „polskich orłów" sięgnęło zenitu na przełomie lat 20. i 30., gdy zaczęli odnosić pierwsze sukcesy na arenie międzynarodowej (Chrobak 56).

Dla odbiorcy młodzieżowego utwory tego rodzaju pisali między innymi Kornel Makuszyński (Skrzydlaty chłopiec, 1934), Zofia Dromlewiczowa (Rycerze przestworzy, 1934) Edmund Jezierski (Wtadca przestworzy, 1930), Maria Kann (Pilot gotów!, 1938) czy Kazimierz Andrzej Czyżowski (Maciek pierwszy król powietrza, 1924). Ich popularność sprawiła,

że tematyka sportowo-turystyczna wniknęła w tkankę międzywojennej literatury fikcjonalnej i niefikcjonalnej adresowanej do młodych, czego skutkiem była zaskakująca obfitość form fabularnych: od podróży krajoznawczych, historii narciarskich, taterniczych, żeglarskich, morskich, poprzez przygody harcerskie, skautowskie aż po wyprawy polarne... (Chrobak 58).

Poczesne miejsce wśród nich zajmowały powieści przygodowe, służące upowszechnieniu idei kolonialnej. Ich autorami byli Bohdan Pawłowicz (Chłopiec z piniorowych lasów, 1934) Jerzy Giżycki (Biali i czarni: fragmenty kolonialne, 1934; Na Czarnym Ladzie, 1935), Kazimierz Warchałowski (Na krokodylim szlaku, 1936), Janusz Makarczyk (Przez morza i dżungle, 1932) i wielu innych. Protagoniści tych utworów, zwyciężając $\mathrm{w}$ konfrontacji z nieprzyjazną przyrodą i szwarccharakterami, zaświadczali o zasadności sanacyjnych roszczeń imperialnych i, co najważniejsze, dawali znać Jankom i Zosiom, że przygoda kolonialna jest w zasięgu ręki. „Wyobraźcie sobie, że jesteśmy Livingstonami i Stanleyami" (Ossendowski 1930: 20), mówi do rodzeństwa jeden z bohaterów Małych zwycięzców Ferdynanda Antoniego Ossendowskiego w momencie, kiedy powielając gesty dorosłych odkrywców wiktoriańskich, nadają miejscom w nieznanej, odludnej okolicy swoje własne imiona. Lektura powieści w podobny sposób przekonywała, że Stanleyem, chociażby „małym", może stać się w przyszłości każdy czytelnik.

Gdyby postaci literackie miały potomstwo oraz o ile zaszłyby dodatkowe okoliczności, jak chociażby poligamia lub promiskuityzm bohatera Wpustyni i w puszczy, to wszyscy chłopcy z młodzieżowej prozy kolonialnej lat trzydziestych mogliby być synami pięćdziesięcioletniego Stanisława Tarkowskiego. Analogia nie wyczerpuje się $\mathrm{w}$ podobieństwie charakterologicznym, niekiedy także obejmuje identyczność próby inicjacyjnej, jakiej zostają poddani z dala od bezpiecznej przestrzeni domowej, w obcym otoczeniu kulturowym i bez wsparcia dorosłych. Kolonie stają się dla nich symboliczną przestrzenią przejścia z chłopięctwa w wiek męski. W młodzieżowych powieściach Ossendowskiego to jednak nie odległość geograficzna ani nie politycz- 
ny status regionu, w którym rozgrywa się akcja, stanowią decydujące kryterium wyboru. Liczy się natomiast radykalna obcość kulturowa, a jej zrozumienie umożliwiać będą etnocentryczne klisze oraz ogólnodostępne stereotypy dyskursu kolonialnego, modyfikowane jedynie ze względu na specyfikę miejsca, w którym toczy się akcja, całość z kolei będzie podporządkowana pedagogice społecznej zgodnej z oficjalną polityką Drugiej Rzeczpospolitej po przewrocie majowym. W utworach autora Leni$n a$ miejscem przełomowej próby mogą się więc stać nawet bagna Polesia (W polskiej dżungli). W przypadku utworu o kajakowej wyprawie czworga młodych warszawiaków na Kresy wtajemniczenie dotyczy jednak zarówno męskości, jak i ideologii państwowej lat trzydziestych z jej specyficzną polityką społeczną i historyczną. Mieszkańcy Polesia, określeni mianem "leśno-bagiennych ludzi” (Ossendowski 1935b: 131), są postrzegani jako dzicy, półzwierzęcy i jako tacy stają się przedmiotem, który należy dopiero ukształtować, co powiela tezy obowiązującego w tamtej epoce dyskursu kresoznawczego, przeanalizowanego niedawno przez Annę Engelking (Engelking 68-94). Bohaterami pozytywnymi, podmiotami konstruktywnych zmian stają się natomiast osadnicy wojskowi oraz leśnicy snujący plany modernizacji, a czworo przyjaciół podąża szlakiem potyczek z czasów wojny 1920 roku, pouczając dorosłych Poleszuków na temat misji cywilizacyjnej Drugiej Rzeczpospolitej na Kresach.

Spośród utworów stanowiących przedmiot niniejszego studium, W polskiej dżungli najsilniej odwołuje się do męskości militarnej oraz mitu niezłomnych strażników kresowej stanicy, broniących miejscową ludność przed agresją i knowaniami podstępnych bolszewików. Poza tym każdy z trzech chłopięcych bohaterów uosabia jedną z męskich praktyk, które w czasach pokoju mogą być uznane za substytut wojny: Olek jest znakomitym wędkarzem, czego dowodzi fakt, że złowił „potwora wodnego" - gigantycznego suma; Staszek to wytrawny myśliwy, który potwierdza umiejętności łowieckie, zabijając w groźnym starciu rysia i odnosząc ranę, która poskutkuje blizną - śladem bólu i heroicznych zmagan. Najwięcej problemów sprawia umiejętność lidera grupy, Jurka, trudno ją bowiem wpasować w określony, męski paradygmat. Gruszczyński jest bowiem fotografem i filmowcem. Gdyby jednak przyjąć za dobrą monetę frazeologizm bezkrwawe łowy, można by uznać, że protagonista prezentuje nowoczesny typ męskości, wiążący się z panowaniem nad technologią i wykorzystywaniem jej do pogłębienia stanu wiedzy. Wszyscy oni, jak wytrawni harcerze, poruszają się po niebezpiecznej, najeżonej pułapkami czyhającymi na mniej doświadczonego turystę, puszczy. Wokół głów bohaterów w trakcie jednego z początkowych epizodów świszczą kule kłusowników, a pobyt u leśniczego Garzyckiego zamykają sceny ujęcia jednego z przestępców i jego ekspiacji $\mathrm{w}$ trakcie pożaru. Powieść otwiera obraz dwóch potężnych basiorów płynących przez poleskie jezioro, by sprawdzić, skąd pochodzi tajemniczy zapach dymu, kończy zaś opis udanego grupowego polowania na wściekłego wilka. Dzięki tej symbolicznej ramie zostaje utwierdzone panowanie Polaków nad dziką, nieprzyjazną przyrodą i mieszkańcami Polesia. 
Przechodząc do analizy tych utworów, które prezentują obrazy "dalszej” egzotyki i w których męskość militarna ulega wyraźnemu osłabieniu na rzecz innych kompetencji, należy poczynić kilka drobnych zastrzeżeń. Ryszard Koziołek, autor artykułu o męskiej inicjacji w twórczości Henryka Sienkiewicza, uznał, iż sednem kolonialnego rytu przejścia ,,jest przywilej zadawania śmierci dzikim istotom..." (Koziołek 128). Jakkolwiek w przypadku Stasia morderstwo na mahdystach uzasadnia powaga sytuacji, a bohater zostaje z niego później rozgrzeszony przez ojca, to jednak stanowi ono fakt niepodważalny, podobnie jak władza, jaką nad afrykańskimi plemionami daje młodemu Polakowi broń palna. W młodzieżowych powieściach przygodowych autora Zwierząt, ludzi, bogów punktem dojścia nie jest uzyskanie tego prawa, byłoby to bowiem sprzeczne $\mathrm{z}$ istotą polskiego projektu kolonialnego, którego rzecznicy chętnie podkreślali głęboki humanitaryzm planowanych działań. Sam Ossendowski zresztą zdecydowanie unikał jakichkolwiek negatywnych uwag związanych z obecnością Polaków w krajach pozaeuropejskich, które częściowo albo całkowicie weszły $\mathrm{w}$ orbitę polityki kolonialnej i związanego z nią systemu globalnego kapitalizmu. I tak, Stanisław Broniewski, ojciec trojga protagonistów Małych zwycięzców, to syn powstańca z 1863 roku oraz wykształcony na politechnice w Paryżu inżynier architekt, który, przepracowawszy kilka lat w Algierii i na Madagaskarze, osiada na stałe $w$ chińskim Tientsinie i zostaje szanowanym członkiem mieszkającej tam społeczności białych. Jak sugeruje narracja, w żaden sposób nie przyczynia się on do wyzysku rdzennej ludności i staje się, po prostu niewinną ofiarą szalejącej wojny domowej. Książki przygodowe Ossendowskiego nieodmiennie też reprodukują najbardziej stereotypową politykę płci, co przejawia się chociażby $\mathrm{w}$ przedstawionym $\mathrm{w}$ powieściach podziale pracy: chłopcy walczą, polują, otaczają troską słabszych oraz zmieniają zastaną rzeczywistość, dziewczynki zaś gotują, szyją i budzą ogólną sympatię jak jedenastoletnia Irenka z Małych zwycięzców czy pełnią funkcję sanitariuszek, opiekujących się rannymi kolegami i leczących miejscową ludność (casus Marysi z W polskiej dżungli).

Niewątpliwie ukochanym „synem” Tarkowskiego byłby Władek Kowalczyk bohater Skarbu z Wysp Andamańskich (1935). Czternastolatek jest dzieckiem Polaków przesiedlonych przez Rosjan na Syberię podczas Wielkiej Wojny. Po licznych perypetiach trafiają oni do Indii Brytyjskich: jego ojciec zostaje cenionym przez angielskiego pracodawcę administratorem plantacji na wyspie Kede, syn zaś pobiera nauki w Rangunie wraz z dziećmi tamtejszej elity: wysoko postawionych Anglików i lokalnych kompradorów. Pan Roman łączy odwagę i siłę charakteru rodem z patriotycznej męskości XIX-wiecznej z cechami męskości kapitalistycznej: pracowitością, spokojem, zdrowym rozsądkiem i dbałością o powierzone dobra (por. Tomasik 13). Niewątpliwie stanowi dla chłopca podstawowy punkt odniesienia jako wzorzec mężczyzny i choć przez większą część akcji jest w historii nieobecny, to Władek, by stać się Władysławem, musi sprostać uwewnętrznionym przez siebie oczekiwaniom rodzica. Młody protagonista po raz pierwszy potwierdza swoją 
wartość jako „człowieka nielichego" i „dobrego Polaka” w trakcie roku szkolnego, kiedy edukuje brytyjskich kolegów w zakresie dziejów Polski. Monumentalność przedstawianych przez niego postaci Stefana Żółkiewskiego, Tadeusza Kościuszki i last but not least - Józefa Piłsudskiego oraz polskich zwycięstw militarnych z wojną polsko-bolszewicką włącznie poświadcza nie tylko właściwą Ossendowskiemu wizję procesu historycznego, gdzie znaczącą rolę odgrywała antyrosyjskość, ale również tworzy podręczny katalog męskich postaw, wobec których chłopiec zajmuje stanowisko. Dydaktyzm opowieści ujawnia się po raz kolejny w momencie, gdy Władek ośmiesza rasizm młodego Anglika, postponującego kolegę z klasy syna birmańskiego notabla. Kowalczyk, metonimia Polaków w ogóle, odróżnia się $\mathrm{w}$ ten sposób od kolonizatorów sensu stricto, którzy dzięki podziałom rasowym mogli sprawować kontrolę nad lokalnymi społecznościami. Jego postawa znajduje uznanie wśród dorosłych: radży, ojca obrażonego i pułkownika, ojca obrażającego. Mężczyźni zapraszają Polaka na obiad, "traktując go jak dorosłego "dżentelmena»" (Ossendowski 1935a: 14). Nobilitacja chłopca do rangi „dżentelmena”, męskiego ideału imperialnych klas wyższych sugeruje jego daleko posuniętą dojrzałość jeszcze przed zawiązaniem właściwej akcji powieści, ale również zdradza sedno brytyjskich „rządów pośrednich” (indirect rule): sojusz lokalnych władców i Europejczyków wspólnie rządzących niższymi klasami społecznymi i wykorzystujących w tym celu narracje etniczne czy różnice religijne.

Epizod ten mimo wszystko nie stanowi jednak momentu przełomowego dla ukształtowania się dojrzałej tożsamości protagonisty. W dobie nowoczesnej wtajemniczenie we wcześniejsze, wymagające heroizmu w tradycyjnym znaczeniu słowa praktyki męskości może mieć miejsce jedynie w czasie wolnym od codziennych obowiązków, o czym świadczy ogólnoświatowa kariera skautingu:

Celem obozów, szkoleń, ćwiczeń było nauczenie chłopców, jak przetrwać poza domem. Cecha niezbyt przydatna w nowoczesnym świecie, co oznacza, że jej źródłem jest świat kolonii. Symulowana inicjacja poprzez skauting opierała się na zasadzie, że dopóki chłopiec nie potrafi przetrwać samodzielnie poza domem, nie może być nazywany mężczyzną (Koziołek 134).

W Małych zwycięzcach stabilną egzystencję Broniewskich zakłóca wybuch wojny, w konsekwencji czego, podobnie jak inni Europejczycy, ewakuują się oni samolotem z Tienstsinu. Kolejne wypadki jak tajfun, przymusowe lądowanie na pustyni Gobi oraz zaginięcie dorosłych: ojca i pilota sprawiają, że troje dzieci: Henryk, Romek oraz Irenka, musi polegać wyłącznie na własnych siłach. Z kolei w powieści o perypetiach Władka Kowalczyka przygoda zaczyna się dopiero w momencie, gdy Władek przybywa na Kede, by spędzić tam wakacje. Już na samym początku pojawiają się trzy istotne później komponenty: wątek podróżujących w to samo miejsce angielskich kryminalistów, których obecność wprowadzi istotne zawikłania fabuły 
i umożliwi bohaterowi przejście szeregu prób, czyniących go finalnie mężczyzną; motyw spotkania z tubylczym chłopcem Dżairem, w opozycji do którego młody Polak będzie budował własną autoidentyfikację; obraz nędzy rdzennego ludu Minkopi ${ }^{4}$ i jego związki z ideologią tekstu. Omówmy więc te elementy po kolei.

Wyspy Andamańskie cieszą się złą sławą od chwili, gdy w zamierzchłej przeszłości, najprawdopodobniej w XVII wieku, przybył na nie portugalski pirat Diego Anda, który skłócił mieszkańców, skłaniając część z nich do prowadzenia łupieżczego procederu. Po kilku latach został pokonany, ale podział wśród rdzennych Minkopi trwał przez wiele pokoleń i zaowocował szeregiem wyniszczających wojen, a Andamany długo określano mianem „Wysp Morderców”. Znacznie później brytyjski gubernator Horn uśmiercił wodza Jomagę z rodu Tamaranów i zrabował zgromadzone przez niego perły. Właśnie po to, by je odnaleźć, przypłynęli na wyspę zwolnieni z więzienia przestępcy, którzy, sprzymierzeni z górskim plemieniem Kalabonów, porwali Dżaira i Władka. Młody Minkopi, będąc wnukiem Jomagi oraz wodzem plemienia in spe, mógł, jak się spodziewali, udzielić im informacji o skarbie. Wobec oporu chłopców bandyci kazali Kalabonom wrzucić przyjaciół w górską czeluść. Bohaterowie po przejściu podziemnego labiryntu znaleźli szczątki Jomagi oraz trafili do tajnej siedziby Andy, gdzie odkryli zrabowane przez niego kosztowności. Po wyjściu na powierzchnię cudem poznali plany bandytów, którzy odnaleźli skarb Tamaranów i planowali porwać statek ekspedycji naukowej, by uciec nim do Ameryki Południowej. Władek uratował jednak przed nimi załogę okrętu i powiadomił lokalną policję, która ujęła kryminalistów.

Istotę przyspieszonego procesu dojrzewania bohatera znacznie lepiej naświetla jednak drugi z kluczowych wątków tekstu, czyli relacja Kowalczyka z Dżairem. Młody tubylec jest młodszy od Polaka, nie liczba lat usprawiedliwia jednak wieczny paternalizm Władka wobec „czarnego chłopaka” (Ossendowski 1935a: 74), ale właściwe uczniowi ranguńskiego liceum przywileje rasowe. Ujawnienie tego faktu pozwala również wyjaśnić drugorzędną, niemal służebną rolę wielbionego przez współplemieńców tubylca $w$ domu polskich plantatorów, jak również zinterioryzowany przez niego kompleks niższości. Protekcjonalny stosunek Polaka do Minkopi stanowi $\mathrm{w}$ istocie replikę najbardziej typowego dla rzeczywistości kolonialnej schematu kontaktu międzykulturowego: spotkania "dorosłego” Europejczyka $\mathrm{z}$ "dziecinnym” dzikim. Po stronie Dżaira stoją bowiem nieskrępowane emocje, skłonność do płaczu, naiwność, wiara w zabobony, niezdecydowanie i tendencja do nieusprawiedliwionego okrucieństwa. Z kolei Władek uosabia racjonalizm, potrafi panować nad afektami, cechuje się wynalazczością, odwagą oraz determinacją w dążeniu do celu. Po raz pierwszy męstwo młodego Kowalczyka ujawnia się, kie-

$4 \mathrm{~W}$ istocie słowo Minkopi nie oznaczało odrębnego plemienia, ale stanowiło zbiorczą kategorię określającą ludność Wysp Andamańskich jako taką. W takim znaczeniu wykorzystał je np. Ignacy Radliński w książce o wyraźnie ewolucjonistycznym nachyleniu pt. Przeszłość w teraźniejszości. Zbiór dociekań i rozważań spoteczno-naukowych (Warszawa 1901). 
dy ratuje kolegę z paszczy rekina, a jego wielkoduszność wynikającą z rzekomych standardów kultury zachodniej potwierdza epizod, gdy wpływając na decyzję Dżaira, ochrania kalabońskiego jeńca przed śmiercią z rąk rozwścieczonych Minkopich. Właściwą próbą, z której wychodzi zwycięsko, jest jednak pobyt w podziemnych jaskiniach - miejscu, gdzie kumuluje się zbrodnicza przeszłość archipelagu ciążąca nad mieszkańcami do czasów współczesnych. Podczas gdy Dżair wylewa hektolitry łez, Władek, korzystając ze zdobytej w szkole wiedzy ${ }^{5}$, tworzy przedmioty umożliwiające im wyjście z kolejnych opresji, a każdą zagadkę tłumaczoną przez tubylca ingerencją sił nadprzyrodzonych objaśnia jako efekt działania naturalnych procesów. Ten wątek inicjacji wiąże się więc ewidentnie z odyseją nowoczesnego rozumu, przedstawioną w Dialektyce oświecenia przez Theodora Adorna i Maxa Horkheimera. Na podobną genealogię kolonializmu zwróciła uwagę Leela Gandhi, odnosząc się do Foucaultowskiej analizy tekstu Co to jest Oświecenie? Immanuela Kanta:

Zamiast odzwierciedlać radykalną różnorodność natury ludzkiej, ogranicza ona rzekomo uniwersalne struktury istnienia ludzkiego do normatywnego stanu dojrzałej racjonalności - wartości, która sama wyłania się ze specyficznej historyczności społeczeństw europejskich. Wynika stąd, że ten opis „ludzkości” wyklucza możliwość dialogu z innymi sposobami bycia człowiekiem $\mathrm{i}, \mathrm{w}$ istocie, powołuje do istnienia i wprowadza do obiegu pojęcie „nie-dorosłego" jako „nie-człowieka” (Gandhi 36).

Zgodnie z tą logiką Polak konsekwentnie, od samego początku stosuje wobec autochtona specyficzną pedagogikę wstydu, ośmieszając jego niedojrzałość, wpajając weń standardy europejskiej męskości hegemonicznej i przygotowując go do przyszłej roli społecznej: „Tylko nie waż się beczeć, bo powiem twoim Minkopi, że jesteś baba, nie mężczyzna, który zamierza stać się wodzem!" (Ossendowski 1935a: 40); "Należy [...] stać się silnym mężczyzną, który nie zna strachu, wahań i łez” (Ossendowski 1935a: 79). W konsekwencji Dżair, który dąży do uznania ze strony białego, reprezentującego autorytatywny, , jedyny słuszny" dyskurs, uwewnętrznia sugerowane praktyki, czyniąc je częścią własnego, męskiego habitusu. Jego metamorfozę ze zdziwieniem i radością obserwują Kowalczyk oraz Edyta Webb - nastoletnia angielska szczebiotka, którą chłopcy poznają podczas ostatnich dni wakacji. To właśnie ona, niedorosła kobieta, wprost potwierdzi ukształtowaną tożsamość genderową młodego Polaka, nazywając go „prawdziwym mężczyzną” (Ossendowski 1935a), sam chłopiec zaś da kolejny popis męskiej sprawności i odwagi, broniąc dziewczynę przed atakiem kobry.

5 Szkolne kompetencje wykorzystują również bohaterowie Małych zwycięzców. Henryk dzięki wiedzy geograficznej i historycznej oswaja obcą przestrzeń, a informacje z chemii pozwalają mu uzyskać sól oraz wytwarzać mydło z ługu, tłuszczu i wyciągu roślinnego. 
Co ciekawe, opisana dialektyka "dorosłości” i „dziecinności” w ogóle nie występuje na kartach Małych zwycięzców ${ }^{6}$. W tym przypadku odpowiednikiem Dżaira jest Czultun - książę mongolskiego plemienia Czacharów. Podobnie jak w przypadku Władka i „małego wodza”, również tutaj Europejczyk (i to dwukrotnie!) ratuje życie tubylcowi, co skutkuje zawiązaniem między nimi więzi dozgonnego „braterstwa”. Młody Mongoł staje się jednak równorzędnym partnerem chłopców, a jego wiedza o tajnikach roślin, sekretnych miejscach i zwyczajach zwierząt pozwala im nie tylko opuścić niegościnną pustynię, ale również zdobyć drogocenny żeń-szeń, który postanawiają spieniężyć, by przynajmniej częściowo odzyskać utracony w wojennej zawierusze rodzinny majątek. Co więcej, w finale utworu przyjaciel Polaków, wódz plemienia, walczącego z Chińczykami oraz Sowietami [sic!], wypowiada słowa pełniące funkcję dydaktyczną, skierowane zarówno do bohaterów, jak i do dziecięcego odbiorcy utworu: „Kochajcie wolność nad wszystko! Brońcie swojej wolności i innym pomagajcie stawać się wolnymi!" (Ossendowski 1930: 86).

Władek, sam jeszcze nie do końca ukonstytuowany jako dojrzały, męski podmiot, stanowi więc siłę sprawczą analogicznych przemian w świadomości innego młodego człowieka, dla którego jest niepodważalnym autorytetem. I choć narracja, jak sygnalizowałem, skrzętnie zaciera ślady uprzedzeń rasowych, to jednak właśnie one umożliwiają taki a nie inny podział ról między bohaterami. Co więcej, do samego końca historii Polak jest określany przez Minkopi mianem „dużego wodza" w odróżnieniu od wodza właściwego, którego prawo do władzy gwarantuje tradycja i autoryzuje brytyjska administracja, czyli Dżaira, nazywanego wodzem "małym". Jako taki stanowi on jedynie narzędzie w ręku faktycznego rzecznika zmiany - czternastoletniego apostoła mission civilisatrice. Narracja utworu od samego początku przekonuje bowiem czytelnika, że tubylcy skazani są na zagładę, o ile nie zostaną podjęte konsekwentne działania wdrażające zdobycze nowoczesnej higieny i medycyny. Źródłem epidemii dziesiątkujących mieszkańców Kede jest rzekomo brak dbałości o czystość w domostwach, do których czytelnik zagląda oczyma Władka, a nie to, co - jak dowodzą historycy - stanowiło faktyczną przyczynę depopulacji Wysp Andamańskich, czyli alkoholizm oraz przywiezione przez Europejczyków choroby:

Ciemne i brudne, pod stożkowatą powałą trzcinowej strzechy zasnute były czarnymi płachtami pajęczyn; jaszczurki pełzały po ścianach; myszy śmigały wśród śmieci i słomy, okrywającej klepisko z gliny. Chłopak nie spostrzegł tam ani stołów, ani zydli. Pośrodku chatki leżało kilka kamieni, gdzie widniała gruba warstwa popiołu, gdyż w nocy

6 W powieści tej, w porównaniu ze Skarbem Wysp Andamańskich, znacznie bardziej rozbudowane jest tło etnograficzne i historyczne, stosunkowo wiernie oddające realia terenów dzisiejszej Mongolii Wewnętrznej z końca lat dwudziestych XX wieku. Niewątpliwie znaczącą rolę odegrały wiedza i doświadczenie samego Ossendowskiego, który na Dalekim Wschodzie spędził, z przerwami, prawie dwie dekady. 
palono tu ognisko, aby dymem jego odpędzać moskity, a nawet zakradające się tu nieraz żmije. Pod ścianą leżała kupa brudnej, cuchnącej słomy - ohydne legowisko mieszkańców (Ossendowski 1935a: 33).

W opisie skumulowane zostały wszystkie możliwe atrybuty obrzydliwości dowodzącej ludzkich zaniedbań oraz niebezpiecznego przywiązania do tradycji, które staje na przeszkodzie w przyjęciu zdobyczy cywilizacji: brud, pajęczyny, odstręczająca woń, obecność wstrętnych gadów czy, o czym narrator wspomina nieco później, kości zmarłych krewnych. Brak higieny dotyczy również najbliższej okolicy chat, gdzie bujnie pleni się roślinność, a ludzie i zwierzęta brodzą w odpadkach, oraz samych ciał autochtonów, które wydzielają ostry zapach potu (Ossendowski: 1935a: 36-37).

W książce Imperial Leather Anne McClintock wnikliwie prześledziła związki między "tym, co domowe” (ang. domestic) oraz czasownikami udomowić i cywilizować (ang. to domesticate). Z analiz badaczki wynika, że w drugiej połowie XIX wieku czystość ciała, ubioru i domu oraz służące jej zachowaniu rytuały zaczęły odgrywać kluczową rolę w wyznaczaniu „porządku hierarchii społecznych” (McClintock 33), stając się jednym ze znaków klasowej czy rasowej dystynkcji. Czystość więc to nie tylko wymóg zdrowotny czy estetyczny, ale stan, który powinien być przedmiotem troski jednostki i być nieustannie kultywowany. McClintock skupia się również na „rasizmie towarowym” (commodity racism), który „w specyficznie wiktoriańskich formach reklamy i fotografii, imperialnych wystawach i ruchu muzealnym przekształcił narrację imperialnego postępu w masowo produkowane spektakle konsumpcyjne" (McClintock 33). W kontekście działań Kowalczyka, owej swoistej formy XIX-wiecznego kolonializmu higienicznego, istotna wydaje się analizowana przez autorkę reklama „Pear's Soap” z 1899 roku, która nawiązuje do słynnego Kiplingowskiego wiersza White Man's Burden i w kontekście której „misja cywilizacyjna" okazuje się imperatywem bezwzględnej puryfikacji:

Pierwszy krok, by ulżyć Brzemieniu Białego Człowieka, wiedzie poprzez naukę cnoty czystości. Pear's Soap jest potężnym czynnikiem w rozjaśnianiu ciemnych zakątków ziemi, w miarę jak postępuje cywilizacja, zajmując jednocześnie najwyższą pozycję wśród najbardziej wykształconych warstw... (Mc Clintock 32).

To właśnie Władek poucza Dżaira, w jaki sposób powinien przekształcić przeklęty skarb w błogosławieństwo wyspy. Młody tubylec, idąc za jego sugestiami, postanawia w przyszłości sprowadzić na Kede europejskich lekarzy i nauczycieli, którzy „wyczyszczą” tubylcze stajnie Augiasza oraz „oświecą” mieszkańców. Czternastolatek doprowadza również do pojednania między Minkopi i Kalabonami, którzy, zanim w okolicy pojawili się zachodnioeuropejscy awanturnicy, stanowili jedno plemię. Utwór zamyka następujący fragment: 
Przeminęła też tajemnica Wysp Morderców, gdzie niegdyś panował okrutny i drapieżny „Postrach Mórz”, a teraz marzył o mądrych i sprawiedliwych rządach mały wódz, który miłował swój lud i te wyspy zielone, jak gdyby uśpione cichym poszumem oceanu (Ossendowski 1935a: 90).

W ten sposób działania Władka Kowalczyka przywracają mieszkańcom zagubioną harmonię. Nie jest to już jednak naiwna sielanka przednowoczesna, ale narodziny nowej, cywilizowanej wspólnoty. A że kontrolowanej przez angielskich sahibów i całkowicie podporządkowanej ich interesom, to już całkiem inna, całkowicie w historii zignorowana kwestia.

Pomijając przemilczenia narracji Ossendowskiego wynikające z ograniczeń obowiązującej wówczas episteme, sformułujmy w ramach podsumowania kilka wniosków. Protagoniści analizowanych powieści, mali „Livingstonowie i Stanleyowie” przykrojeni do oczekiwań kilkunastoletnich czytelników w pełni wpisują się we wzorzec kolonialnego skauta ${ }^{7}$ łączącego zaradność w skrajnie trudnych warunkach z określoną postawą etyczną. Na ich portret psychologiczny składają się zarówno cechy idealizowanych, zachodnioeuropejskich kolonizatorów, jak i tradycyjnie wiązane z Polską rycerskość oraz patriotyzm. Można więc uznać ich za wzorzec postaw moralnych i zachowań praktycznych, preferowanych przez rzeczników idei kolonialnej okresu Drugiej Rzeczpospolitej. Teksty, których są bohaterami, ograniczają się do reprodukcji wzorców kulturowych: sanacyjnych ideałów obywatela i państwa narodowego (W polskiej dżungli), postoświeceniowego racjonalizmu czy konceptu „misji cywilizacyjnej” (Skarb Wysp Andamańskich), a stopień, w jakim są przesycone dydaktyką oraz informacjami encyklopedycznymi, sprawia, że egzotyczna przygoda, podobnie jak miało to miejsce na łamach młodzieżowej wersji czasopisma „Polska na Morzu”, zostaje często zepchnięta na dalszy plan, stając się jedynie pretekstem do ilustrowania założonych tez ideologicznych.

\section{BIBLIOGRAFIA}

\section{Literatura podmiotu}

Ossendowski, Ferdynand Antoni. Mali zwycięzcy (Przygody dzieci w pustyni Szamo). Lwów-Warszawa: Książnica-Atlas, 1930.

Ossendowski, Ferdynand Antoni. Skarb Wysp Andamańskich. Warszawa: Instytut Wydawniczy Biblioteka Polska, 1935a.

Ossendowski, Ferdynand Antoni. W polskiej dżungli. Warszawa-Lwów: Państwowe Wydawnictwo Książek Szkolnych, 1935b.

7 Wielu harcerzy w dwudziestoleciu faktycznie działało w szkolnych kołach Ligi Morskiej i Kolonialnej (zob. Kowalski 73). 


\section{Literatura przedmiotu}

"Czarnoskóry żołnierz w pochodzie uzbrojony w karabin 7,9 mm Mauser wz. 1898 i pas z ładownicami". Narodowe Archiwum Cyfrowe. Web. 31.08.2018. <https://audiovis.nac.gov.pl/ob$\mathrm{raz} / 102718 / \mathrm{ced1810d0bc7e06eb07dcb1ca8283ed6/>}$

Adorno Theodor W., Horkheimer Max. Dialektyka oświecenia. Fragmenty filozoficzne. Przeł. Małgorzata Łukaszewicz. Przekład przejrzał i posłowiem opatrzył M.J. Siemek. Warszawa: Wydawnictwo Krytyki Politycznej, 2010.

A.M. (wł. Antoni Małkowski). „Myśli o organizacji”. Skaut. Pismo młodzieży polskiej 6 (1912). S. 3-5.

Budrewicz, Zofia. Lekcje polskiego krajobrazu. Międzywojenna proza podróżnicza dla młodzieży. Kraków: Wydawnictwo Naukowe Uniwersytetu Pedagogicznego, 2013.

Chrobak, Małgorzata. „Proza o tematyce lotniczej dla młodzieży w dwudziestoleciu międzywojennym. Rekonesans". Annales Universitatis Paedagogicae Cracoviensis: Studia ad Bibliothecarum Scientiam Pertinentia 12 (2014). S. 56-68.

Connell, Raewyn. „Hégémonie, masculinité, colonialité”. Przeł. Joëlle Marelli. Genre, sexualité § sociéte 13 (2015). Web. 31.08. 2016. <https://journals.openedition.org/gss/3429>

Engelking, Anna. „«Poleszuk» nieoswojony. Wokół funkcji chłopskości w konstruowaniu polskości”. Teksty Drugie 6 (2017). S. 68-94.

Gandhi, Leela. Teoria postkolonialna. Wprowadzenie krytyczne. Posłowie E. Domańska. Przeł. Jacek Serwański. Poznań: Wydawnictwo Poznańskie, 2008.

Joly, Vincent. „«Races guerrières» et masculinité en contexte colonial. Approche historiographique”. Clio. Femmes, Genre, Histoire 33 (2011). S. 139-156.

Koziołek, Ryszard. „Męskość Stasia”. Znakowanie trawy albo praktyki filologii. Katowice: Wydawnictwo Uniwersytetu Śląskiego, 2011.

Kowalski, Marek Arpad. Dyskurs kolonialny w Drugiej Rzeczpospolitej. Warszawa: Wydawnictwo DiG, 2010.

Lewandowski, Janusz. „Po Dniach Morza”. Morze i Kolonie. Organ Ligi Morskiej i Kolonialnej 8 (1939). S. 4-10.

Makarczyk, Janusz. Widziałem i styszałem. Wspomnienia podróżnicze. Warszawa: Czytelnik, 1957.

Małkowski, Antoni. Skauting jako system wychowania młodzieży. Lwów: Związek polskich gimnastycznych towarzystw sokolich, 1911.

McClintock, Anne. Imperial Leather. Race, Gender and Sexuality in the Colonial Contest. London: Routledge, 1995.

Muszalski, Edward. Harcerstwo (skauting) a wychowanie czlowieka. Warszawa: Księgarnia J. Lisowskiej, 1918.

Pigoń, Stanisław. „Skauting polski wobec zadań wychowania narodowego”. Do podstaw wychowania narodowego. Lwów: Zakład Narodowy im. Ossolińskich, 1921.

Radliński, Ignacy. Przeszłość w teraźniejszości. Zbiór dociekań i rozważań spoteczno-naukowych. Warszawa: Skład główny Gebethnera i Wolffa, 1901.

Sinha, Mrinalini. Colonial Masculinity. The ,Manly Englishman' and the ,Effeminate Bengali' in the Late Nineteenth Century. Manchester-New York: Manchester University Press, 1999. 
Śmieja, Wojciech. Hegemonia i trauma. Literatura wobec dominujacych fikcji męskości. Warszawa: Wydawnictwo Instytutu Badań Literackich, 2016.

Śmieja, Wojciech. „Od ideologii ciała do cielesności zideologizowanej. Sport i literatura w latach 19181939 (wybrane przykłady)". Teksty Drugie 4 (2011). S. 28-48.

Tomasik, Tomasz. „Uwagi do wciąż nienapisanej historii męskości w Polsce”. Pamiętnik Literacki 2 (2016). S. 5-17.

Wojda, Dorota. Polska Szeherezada. Swoje i obce z perspektywy postkolonialnej. Kraków: Wydawnictwo Uniwersytetu Jagiellońskiego, 2016. 
